\title{
APLIKASI MARKETPLACE DENGAN SISTEM LELANG BERBASIS WEB MENGGUNAKAN METODE CONCURRENCY CONTROL (TIMESTAMP)
}

\author{
Mohamad Rifaldi, Ridho Taufiq Subagio, Kusnadi \\ Sekolah Tinggi Manajemen Informatika dan Komputer CIC Cirebon \\ Jl.Kesambi 202, Kota Cirebon, Jawa Barat.Tlp : (0231)220250 \\ e-mail :mohamadrifaldi6@gmail.com, ridho.taufiq@cic.ac.id,kusnadi@cic.ac.id
}

\begin{abstract}
Abstrak
Perkembangan teknologi informasi di era globalisasi ini telah mengalami perkembangan cukup pesat. Seiring dengan pesatnya kemajuan teknologi, banyak manusia mengharapkan teknologi dapat mempermudah aktivitas lebih efektif dan efisien. Lelang merupakan salah satu jenis jual beli yang bersifat menawar ke nominal yang lebih tinggi. Secara konvensional, proses lelang mengharuskan penawar datang ke tempat lelang dan harus direpotkan dengan membawa pulang barang yang dimenangkan tadi.Untuk memanfaatkan potensi kemajuan teknologi informasi yang pesat peneliti menambahkan sistem pelelangan secara online dengan model marketplace dengan cara penggunaan metode concurrency control (timestamp) untuk memberikan proses lelang yang cepat serta menghasilkan data yang akurat.Hasil dari pembuatan sistem lelang ini yaitu penerapan sistem lelang sebagai salah satu inovasi pembeda dengan membuat sistem lelang yang praktis sehingga semua orang, kapan dan dimana saja dapat mengikuti proses lelang dengan peminat yang lebih luas.
\end{abstract}

Katakunci: Online,concurrencycontrol, timestamp.

\begin{abstract}
The development of information technology in this globalization era has experienced quite rapid development. As technology advances rapidly, many people expect technology to make activities more effective and efficient. Auction is one type of buying and selling that bid to a higher nominal. Conventionally, the auction process requires bidders to come to the auction site and must be bothered by bringing home the items won earlier.To take advantage of the potential development of information technology developed by researchers, add an online auction system to the marketplace model by using a concurrency control method (timestamp) to provide a fast auction process and produce accurate data.

The result of making this auction system is the implementation of the auction system as one of the distinguishing innovations by creating an auction system that is practically everyone, at any time and at any time can continue the auction process with a wider interest.
\end{abstract}

Keywords:Auction, online, concurrency control, time stamp

\section{PENDAhuluan}

Perkembangan teknologi informasi di era globalisasi ini telah mengalami perkembangan cukup pesat. Seiring dengan pesatnya kemajuan teknologi, banyak manusia mengharapkan teknologi dapat mempermudah aktivitas lebih efektif dan efisien, hal seperti ini dapat ditunjang dengan teknologi yang cepat pula. Saat ini sebagian besar hal dapat dilakukan secara online dari surat kabar, transaksi perdagangan, promosi suatu produk, hingga data diri dan lokasi suatu tempat dilakukan secara praktis melalui handphone atau menggunakan komputer secara online.

Hal ini berdampak pada meluasnya perdagangan global, tidak cukup bagi seseorang hanya mengandalkan promosi dengan membagikan brosur. Teknologi membatu proses perdagangan dengan adanya marketplace, dimana kita mempunyai lahan atau tempat untuk berjualan dengan jenis produk bervariasi dan kita dapat mempromosikan di internet dengan jangkauan pasar yang sangat luas. Lalu internet dapat berjasa memajukan transaksi jual beli sekaligus media promosi bagi produk kita.

Banyak sekali produk yang dijual melalui internet seperti fashion, otomotif, elektronik dan lain lain. Peneliti melihat peluang yang baik untuk dapat membuat marketplace khusus untuk barang seni seperti lukisan abstrak, siluet, surreal, sculpture, miniatur, replika, kerajinan tangan, barang antik dan lain 
lain. Menurut jurnal ini pada latar belakang dengan judul Aplikasi Toko Online Barang Antik, Ronny[1]"Industri pasar barang seni di indonesia mulai banyak diminati orang, karena semakin banyak jenis barang seni yang muncul mempunyai nilai kreatifitas serta nilai keindahan yang baik”. Menurut jurnal ini potensi pasar barang seni di indonesia untuk saat ini sangat besar, karena banyak sekali kebutuhan para kolektor maupun dari peminat seni karena seiring bertambahnya produk seni di indonesia yang beragam. Untuk itu peneliti menyediakan tempat untuk para pelaku seni dan pengrajin untuk menjual karya seni buatan sendiri serta barang seni yang tidak terpakai atau disimpan dengan tidak baik, jika dilihat nilai seni nya maka barang tersebut masih memiliki harga dan peminat.

Untuk memanfaatkan potensi kemajuan teknologi informasi yang pesat peneliti menambahkan sistem pelelangan secara online didalam marketplace tersebut. Tentunya peneliti ingin membuat marketplace dengan sistem lelang semuanya menjadi praktis, sehingga semua orang, kapan dan dimana saja dapat mengikuti lelang. Karena bagi peneliti pelelangan mempunyai banyak hal positif seperti antusias penawar, cepat, efektif, serta harga yang didapat tinggi.

Menurut jurnal dengan judul Rancang Bangun Sistem Aplikasi E-Lelang Barang Dengan Metode ConcurrencyOfDevelopment, Adhiyan Abdiel Nugraha dan Nova Rijati[2] "Akan tetapi terdapat permasalahan yang timbul pada aplikasi lelang yaitu jika terdapat dua atau lebih user mengeksekusi suatu data dalam bersamaan atau menawar barang diwaktu yang bersamaan akan mengakibatkan data yang diberikan tidak valid atau inkonsisten. Diperlukan sebuah penanganan berupa metode concurrencycontrol yang dapat membuat banyak user bisa mengakses data secara bersamaan". Maka dari itu untuk menghindari masalah tersebut perlu adanya pemberian tanda waktu disetiap data dengan menggunakan teknik timestamp untuk menghasilkan data yang jelas dan konsisten.

\subsection{IdentifkasiMasalah}

Berdasarkanlatarbelakangmasalahdiatasmakapenulismembuatidentifikasimasalah akanmenjadi bahasan yaitu sebagai berikut:

1. Terdapat barang seni yang kondisinya tidak terpakai maupun disimpan secara tidak baik.

2. Beberapa barang seni masih layak digunakan serta memiliki harga jual.

3. Mengikuti kegiatan lelang masih sulit karena perlu datang langsung ke tempat balai pelelangan.

4. Hasil data yang dihasilkan oleh sistem lelang masih menghasilkan data yang kurang tepat, tidak akurat dan inkonsisten.

\subsection{Batasan Masalah} berikut:

Berdasarkanlatarbelakangmasalahdiatas,makapenulisdapatmenguraikanbatasan masalah sebagai

1. Aplikasi web lelang ini hanya digunakan bagi anggota lelang saja.

2. Aplikasi ini tidak tersedia paymentgateway.

3. Aplikasi dibuat dengan menggunakan bahasa pemrograman PHP dengan FrameworkCodeigniter sedangkan untuk database-nya menggunakan MySQL.

4. Mengimplementasikan metode concurrencycontrol (timestamp) di dalam databaseMySQL.

\subsection{Tujuan Penelitian}

Adapunyangmenjadi tujuan dari penelitianyang akan dilakukanadalah :

1. Sistem ini menghasilkan keputusan pemenang lelang dari segi penawaran tertinggi serta waktu tercepat sehingga menghasilkan data pemenang lelang.

2. Dapat membantu pelaku dan pengrajin seni menjualkan barang-barang seni.

3. Penjual akan mendapatkan harga yang tinggi hasil dari melelang produk nya.

4. Mempermudah proses terjadinya kegiatan lelang yang praktis, sehingga kapan dan dimana saja semua orang dapat mengikuti lelang.

5. Sarana tempat bagi pegiat seni untuk menunjukkan kreativitas serta mengekspresikan karyakaryanya.

6. Sistem lelang sebagai salah satu inovasi pembeda, sehingga produk yang dijual, didapatkan dengan memberikan penawaran dengan sistem lelang.

Aplikasi Marketplace Dengan Sistem Lelang Berbasis Web Menggunakan Metode Concurrency Control (Timestamp)-( Mohamad Rifaldi, Ridho Taufiq Subagio, Kusnadi) 


\section{STUDI LITERATUR}

\subsection{Marketplace}

Marketplace merupakan media online berbasis internet (webbased) tempat melakukan kegiatan bisnis dan transaksi antara pembeli dan penjual. Pembeli dapat mencari supplier sebanyak mungkin dengan kriteria yang diinginkan, sehingga memperoleh sesuai harga pasar. Sedangkan bagi supplier/penjual dapat mengetahui perusahaan-perusahaan yang membutuhkan produk/jasa mereka. (Opiida) [3].

\subsection{Lelang}

Lelang atau Penjualan dimuka umum adalah suatu penjualan barang yang dilakukan didepan khalayak ramai dimana harga barang- barang yang ditawarkan kepada pembeli setiap saat semakin meningkat. Serangkaian kegiatan untuk menyediakan barang/jasa dengan cara menciptakan persaiangan yang sehat diantara penyedia barang/jasa yang setara dan memenuhi syarat, berdasarkan metode dan tata cara tertentu yang telah ditetapkan dan diikuti oleh pihakpihak yang terkait secara taat asas sehingga terpilih penyedia yang baik. (Salim HS) [4]

\subsection{Metode Concurrency Control}

Tujuan utama dalam pengembangan database adalah membuat banyak pengguna bisa mengakses data secara bersamaan. Pengaksesan data ini tidak bermasalah jika semua pengguna hanya membaca data dan mereka tidak mengganggu satu sama lain. Tapi ketika dua pengguna atau lebih mengakses database yang sama secara bersamaan dan salah satu melakukan perubahan terhadap data, maka hal ini akan dapat menimbulkan adanya data yang tidak konsisten (inconsistencydata).

Untuk mengatasi adanya kemungkinan inconsistencydata, maka dibutuhkan adanya suatu mekanisme yang mengatur jalannya transaksi pengaksesan data yang sama tersebut, mekanisme ini dikenal dengan istilah concurrencycontrol.

Concurrencycontrol adalah proses pengaturan operasi-operasi dalam banyak transaksi yang berjalan secara simultan pada database tanpa mengganggu operasi pada transaksi lainnya sehingga dapat menghasilkan data yang konsisten. (Choirul Huda) [5].

\section{PERANCANGAN SISTEM}

\subsection{Mekanisme Penggunaan Timestamp}

Setiap transaksi di tandai waktu kehadirannya dalam sistem. Jika transaksi yang lama Ta mempunyai timestamp a, transaksi yang baru Tb diberi timestamp $\mathrm{b}$ dimana a $<\mathrm{b}$. Jika timestamp transaksi a lebih kecil daripada timestamp transaksi $b$, atau $\mathrm{TS}(\mathrm{Ta})<\mathrm{TS}(\mathrm{Tb})$, maka transaksi a(Ta) selalu dilaksanakan sebelum transaksi b(Tb). Contoh lainnya adalah Misalkan ada transaksi T1, T2, dan T3.

Tabel 1. Mekanisme Penggunaan Timestamp

\begin{tabular}{|l|l|l|l|l|}
\hline \multicolumn{1}{|c|}{ WAKTU } & \multicolumn{1}{c|}{ T1 } & \multicolumn{1}{c|}{ T2 } & \multicolumn{1}{c|}{ T3 } & \multicolumn{1}{c|}{ CURRENT } \\
\hline 00.01 .15 & Mulai_transaksi & & & 200.000 \\
\hline 00.01 .10 & $\begin{array}{l}\text { newBid }= \\
\text { currentBid+100.000 }\end{array}$ & & & 200.000 \\
\hline 00.01 .00 & commit & Mulai_transaksi & Mulai_transaksi & 300.000 \\
\hline 00.00 .15 & & $\begin{array}{l}\text { newBid } \\
\text { currentBid }+400.000\end{array}$ & - & 300.000 \\
\hline 00.00 .10 & & & $\begin{array}{l}\text { newBid }= \\
\text { currentBid }+450.000\end{array}$ & 300.000 \\
\hline 00.00 .04 & & commit & commit & 750.000 \\
\hline 00.00 .00 & & galat & & abort/gagal \\
\hline
\end{tabular}

Keterangan :

Di menit-menit terakhir penutupan lelang, terdapat event pada waktu 00.01.00 T2 dan T3 samasama memasuki sistem untuk memulai bid. Untuk T2 bid sebanyak 400.000 dan T3 bid sebanyak 450.000, akan tetapi saat input penawaran berbeda waktu, T2 terlebih dahulu memulai input penawaran berselang 5 detik lalu T3 memulai input penawarannya juga. Tetapi pada saat commit T3 'melaksanakan' commit-nya yang sukses tersimpan di sistem, dan diikuti T2 yang didefinisikan gagal untuk memberi penawarannya 
karena waktu "habis" dan terdapat "galat". Hal ini mendefinisikan bahwa setiap transaksi di tandai waktu kehadirannya dalam sistem. Jika transaksi mempunyai waktu lebih kecil atau terlebih dahulu melakukan transaksi akan dapat dilaksanakan dan tersimpan.

\subsection{UseCaseDiagram}

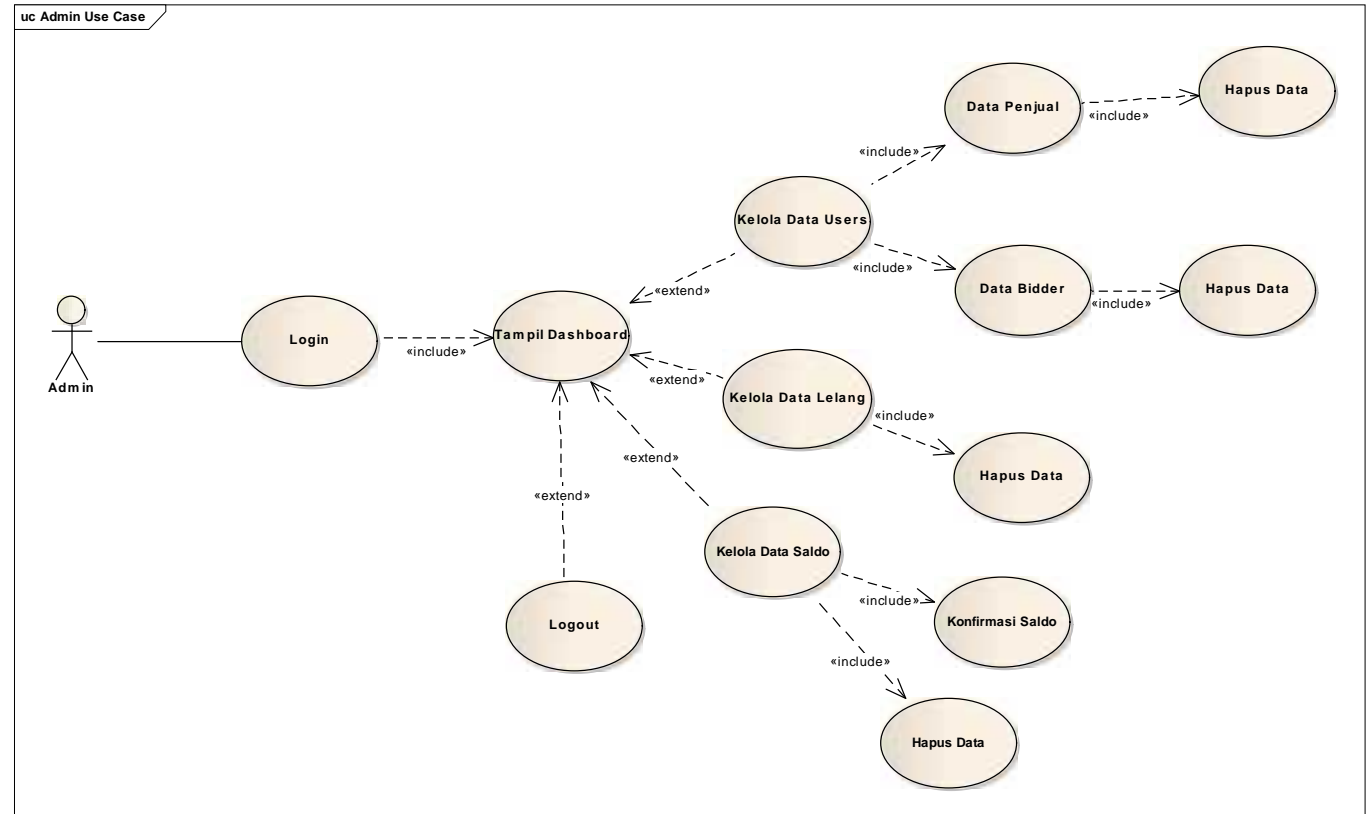

Gambar 1. Use Case Diagram Admin

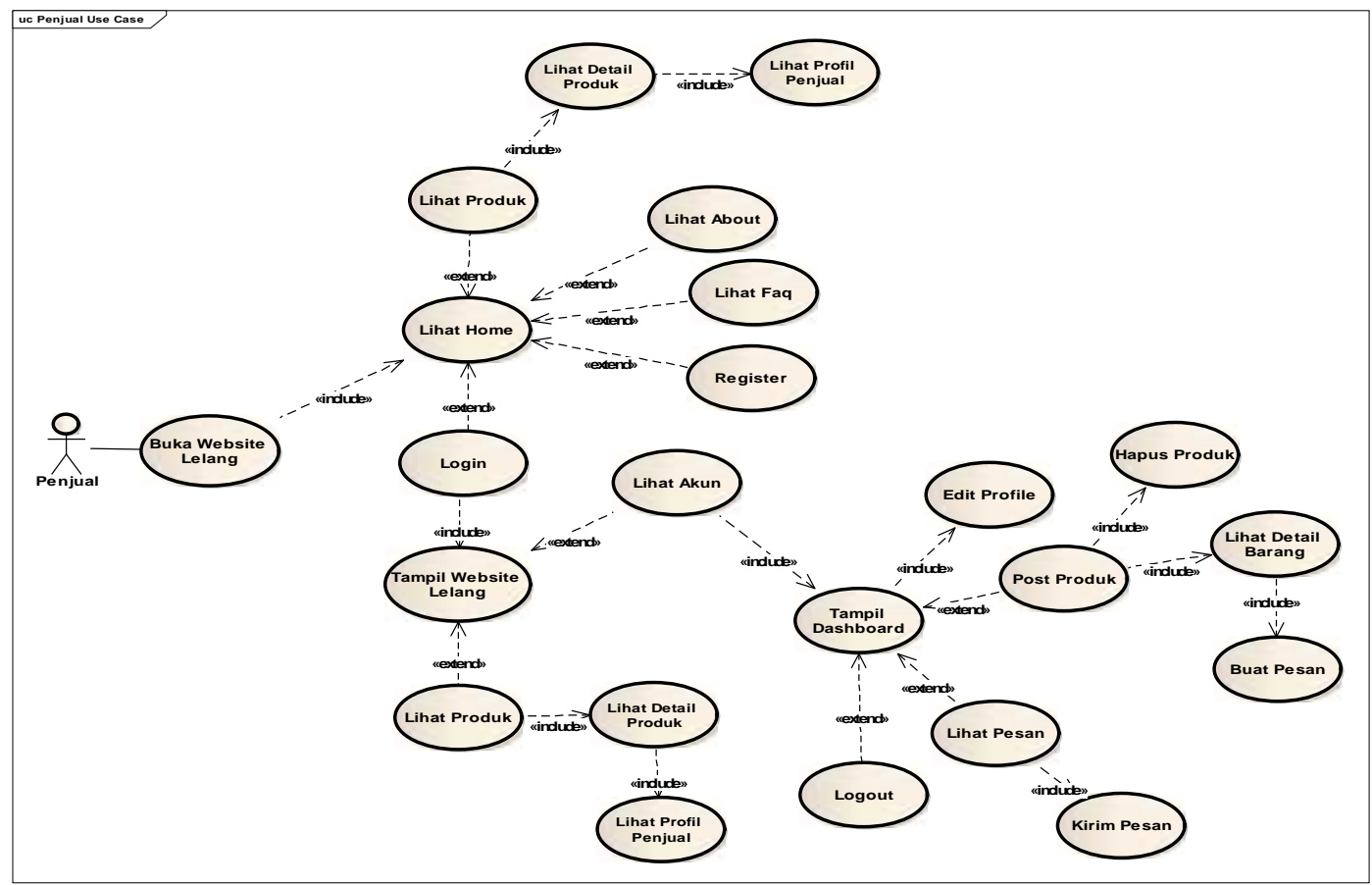

Gambar2. Use Case DiagramPenjual 


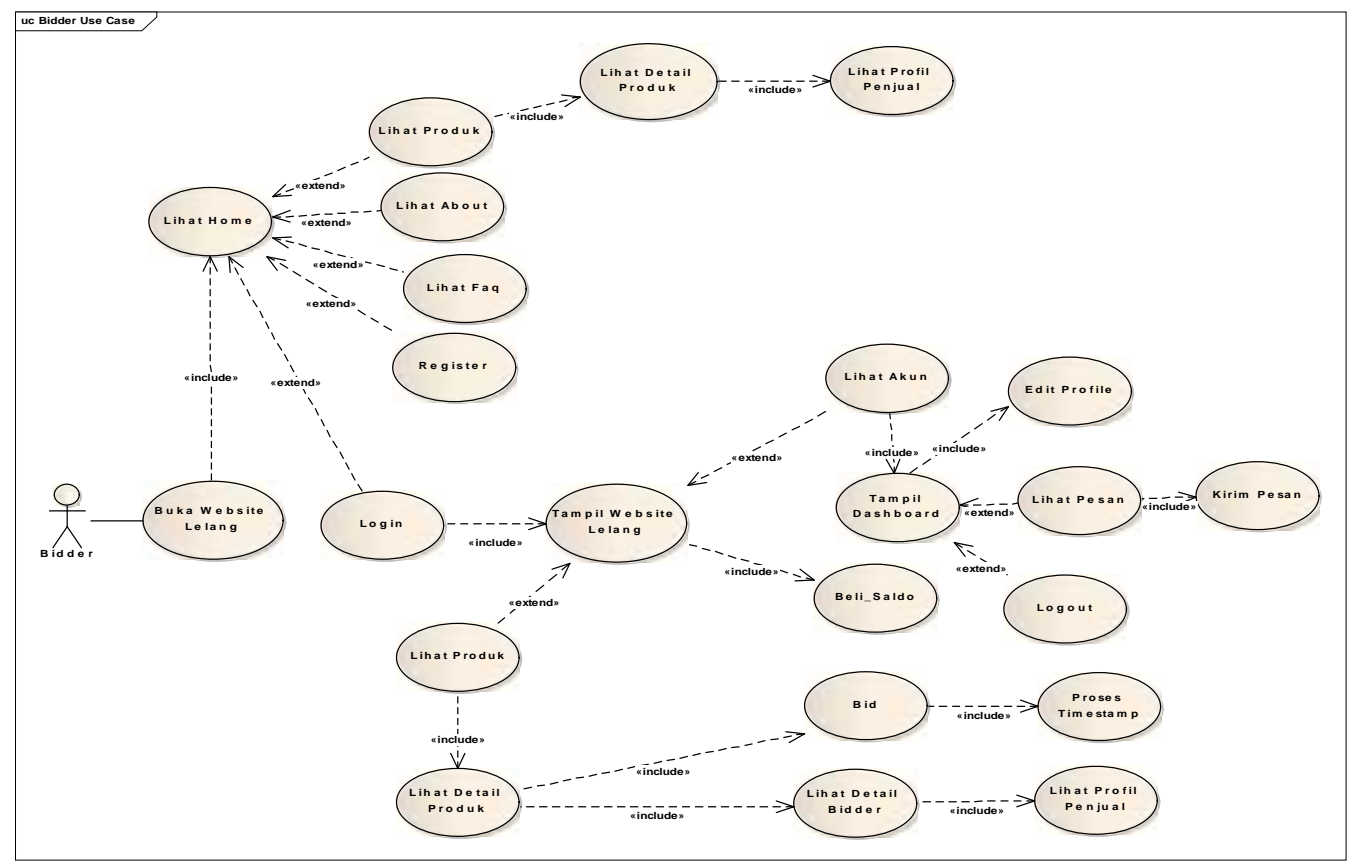

Gambar3. Use Case DiagramBidder

\subsection{ActivityDiagram}

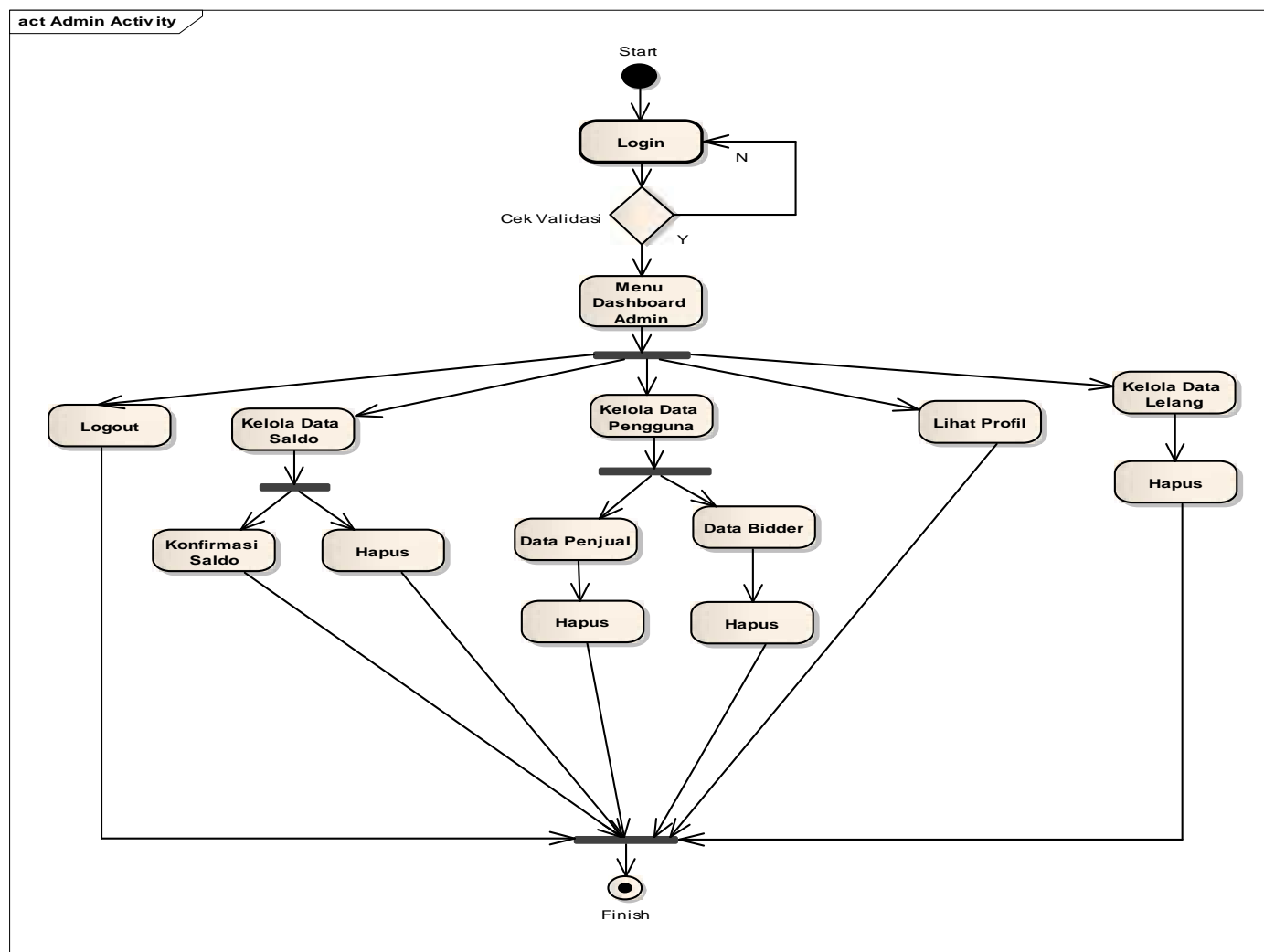

Gambar4.Activity Diagram Admin 


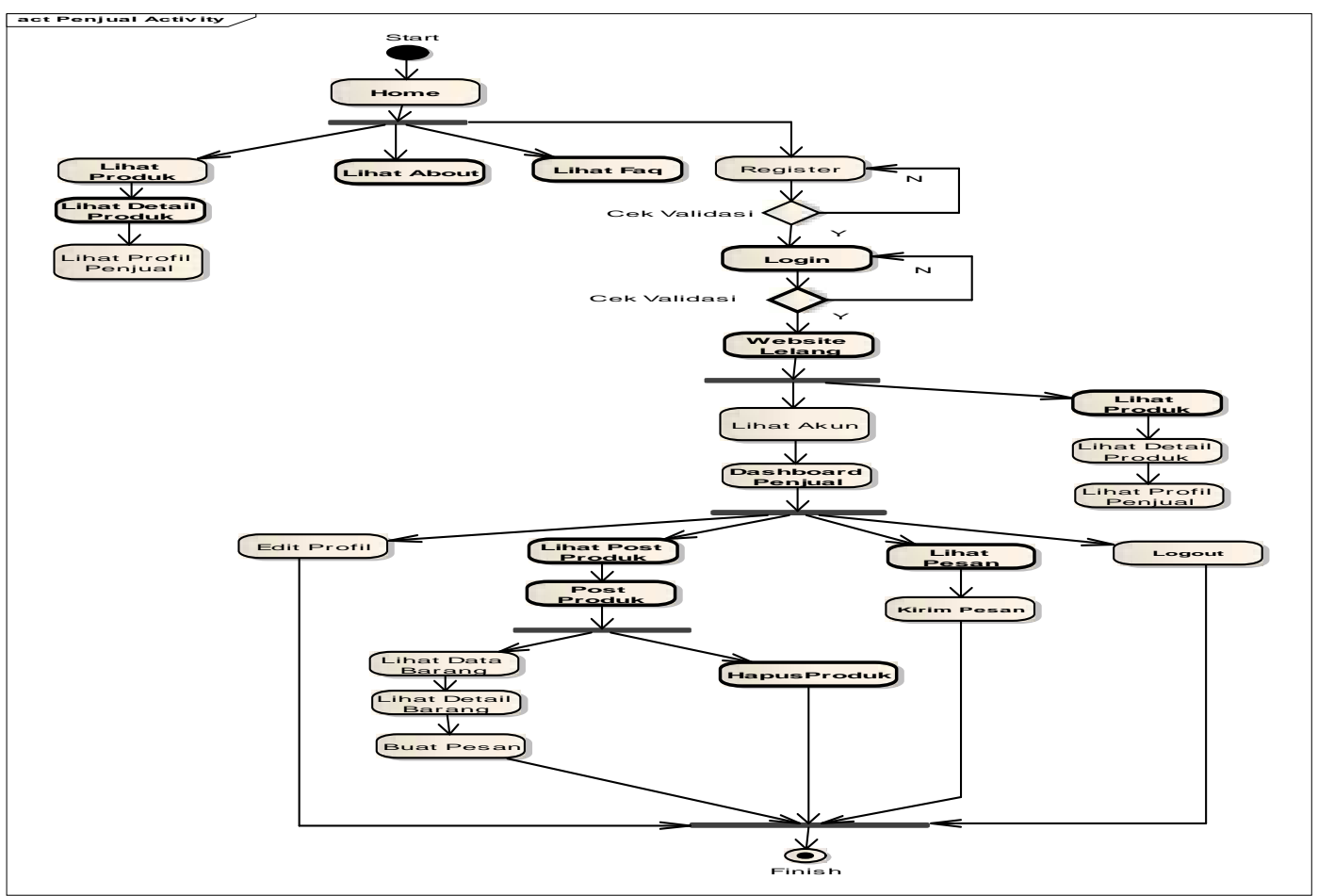

Gambar5.Activity Diagram Penjual

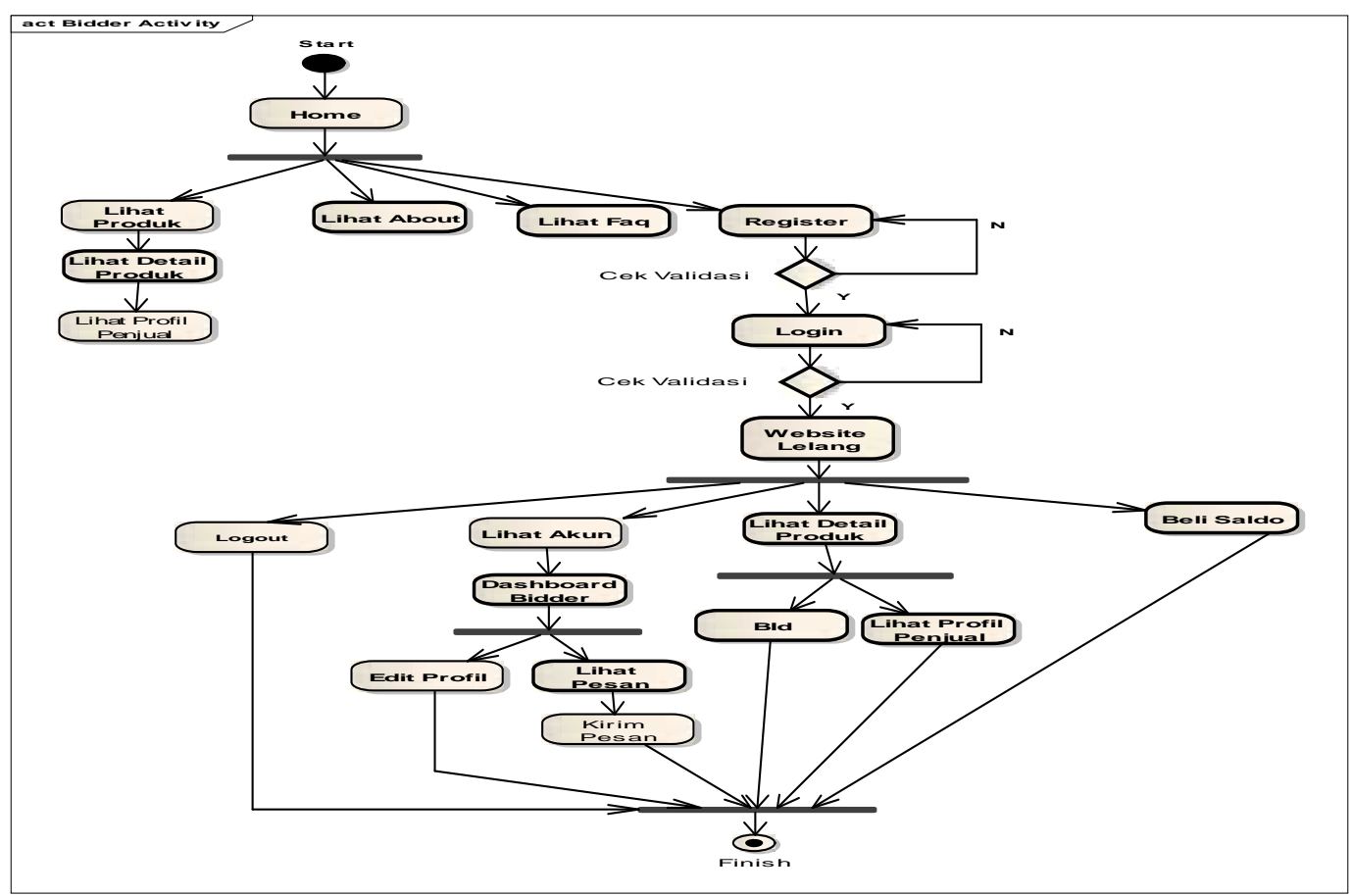

3.4. Class Diagram

Gambar6.Activity Diagram Bidder 


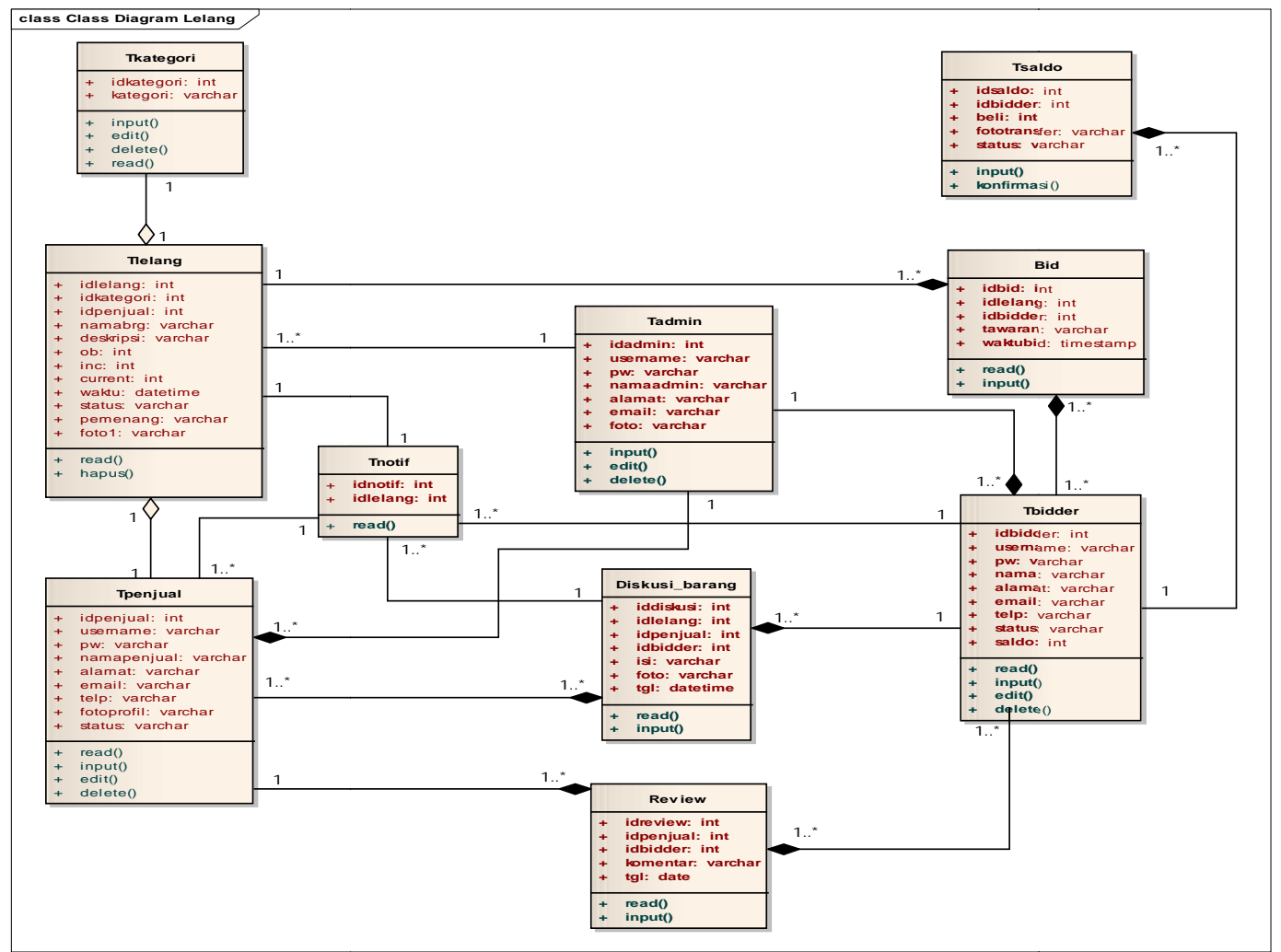

Gambar 7.Activity Diagram Bidd

\section{IMPLEMENTASI SISTEM}

\subsection{TampilanAntarmukaMenu Utama Marketplace}

Tampilan utama marketplace pada bidder ini berfungsi untuk bidder melihat fitur, konten, produk yang sedang dilelang.

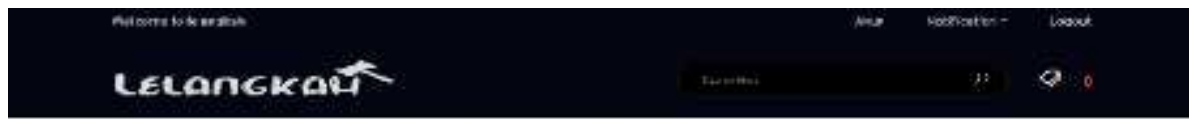

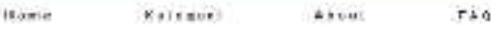

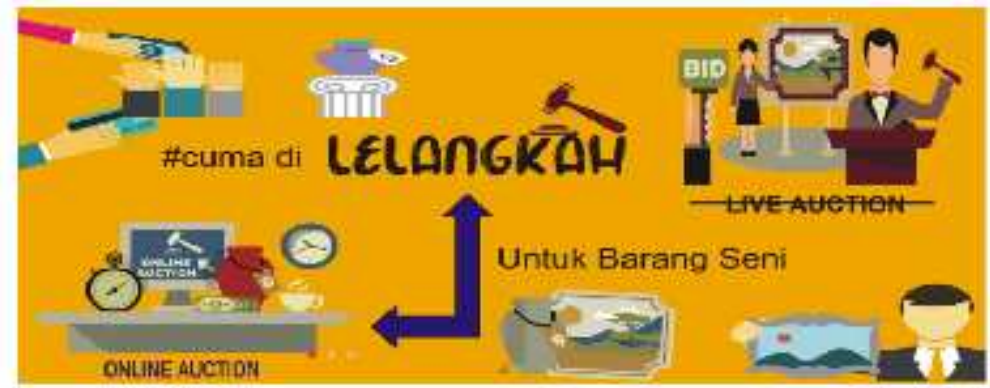

Gambar8.Halaman Menu Utama

Tampilan login utntuk penjual dan bidder ketika ingin masuk kedalam sistem. 


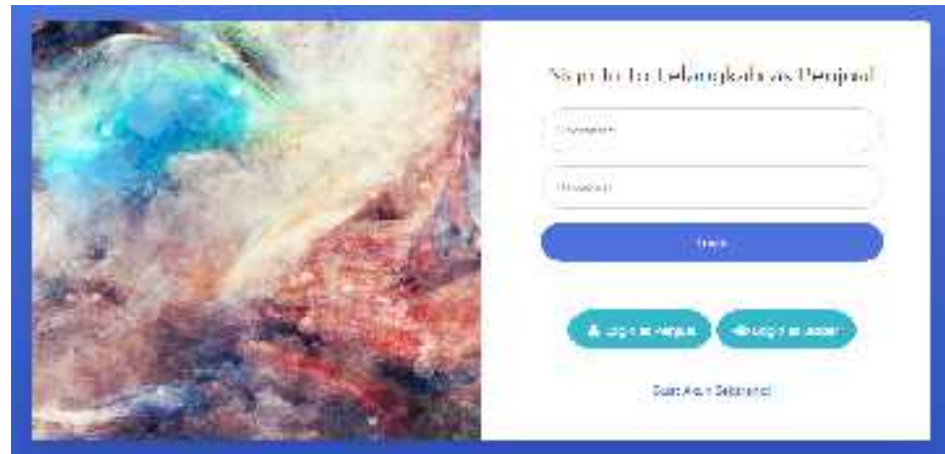

Gambar9.Halaman Login

Tampilan register untuk penjual ketika penjual ingin melelang produk nya.

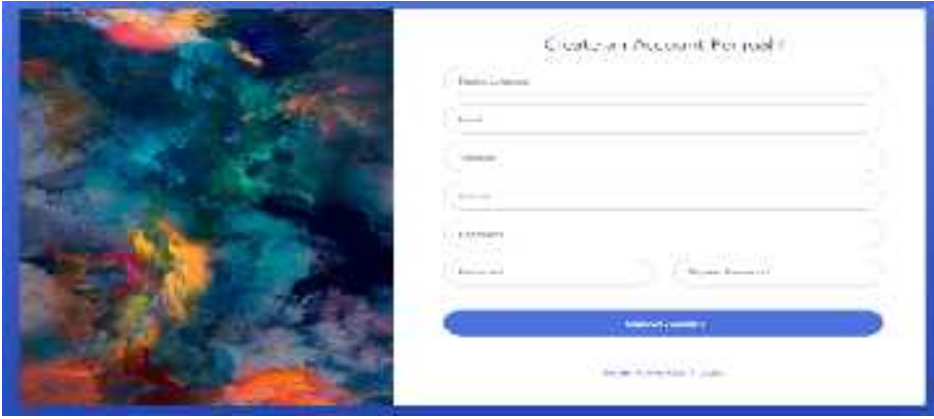

Gambar 10.Halaman Register

\subsection{TampilanAtarmukaPenjual}

Setelah login penjual akan dialihkan ke menu dashboard untuk memulai aktifitas pelelangan.

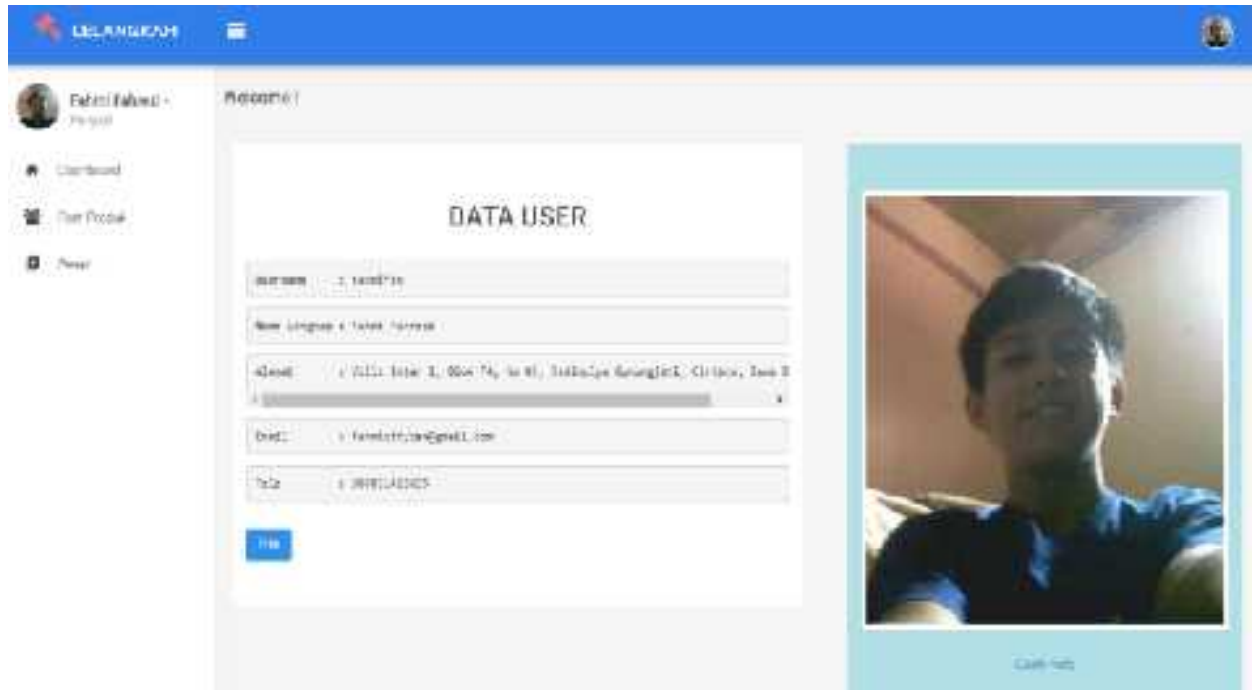

Gambar11.Halaman Menu Utama Penjual

Setelah login penjual akan dialihkan ke menu dashboard untuk memulai aktifitas pelelangan. 


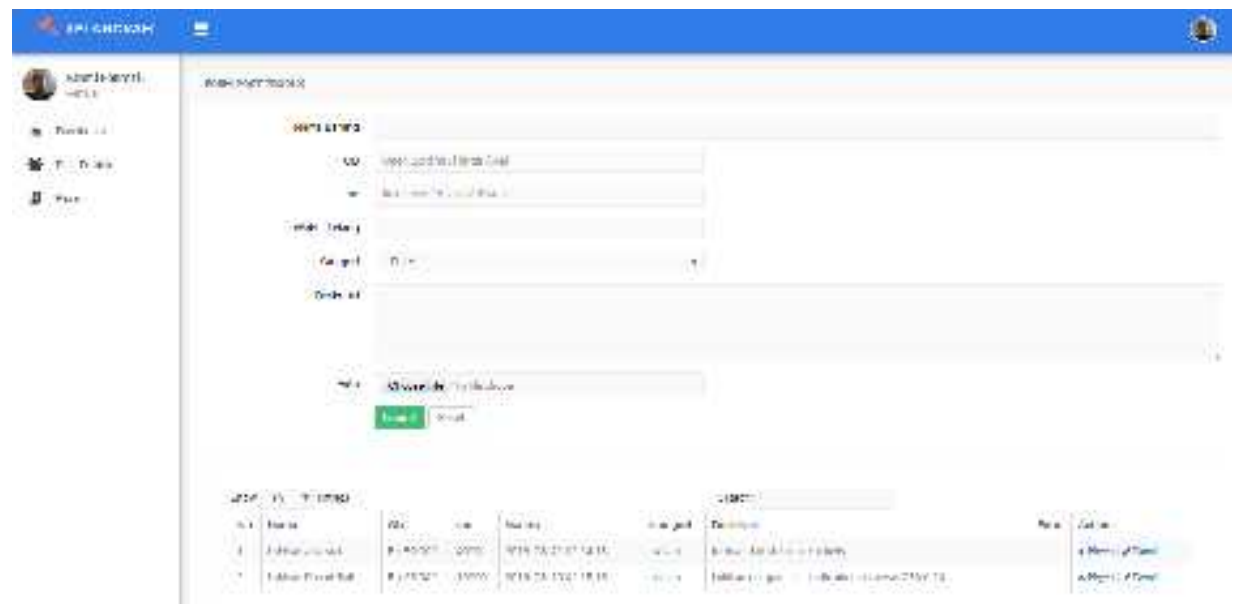

Gambar12.Halaman Menu Post Produk

\subsection{HalamanMenu Edit Profil Penjual}

Penjual dapat mengedit profilnya untuk informasi baru mengenai data profil dirinya.

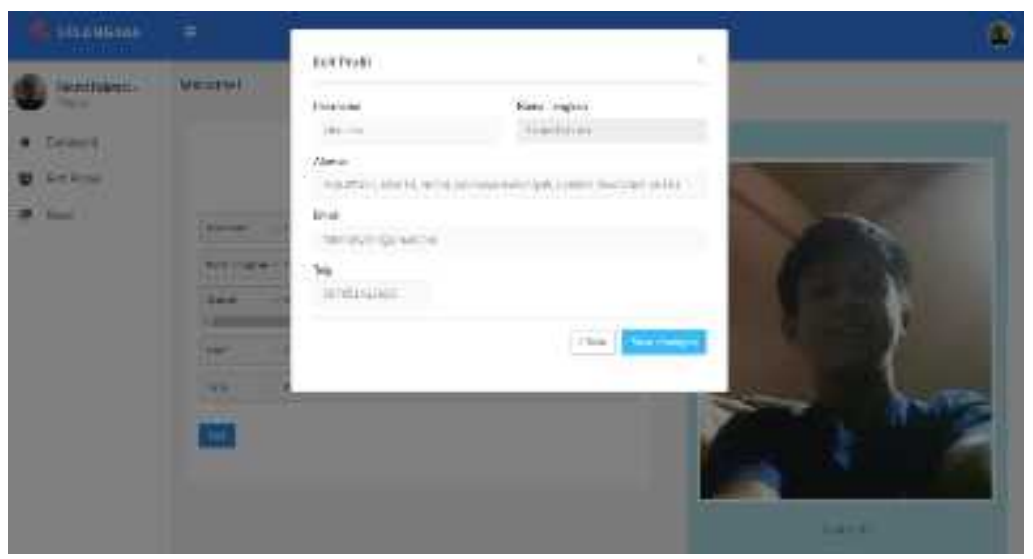

Gambar13.Halaman Menu Edit Profil Penjual

\subsection{TampilanAtarmukaBidder}

Setelah loginbidder dapat ke menu dashboard untuk melihat profil serta kirim pesan.

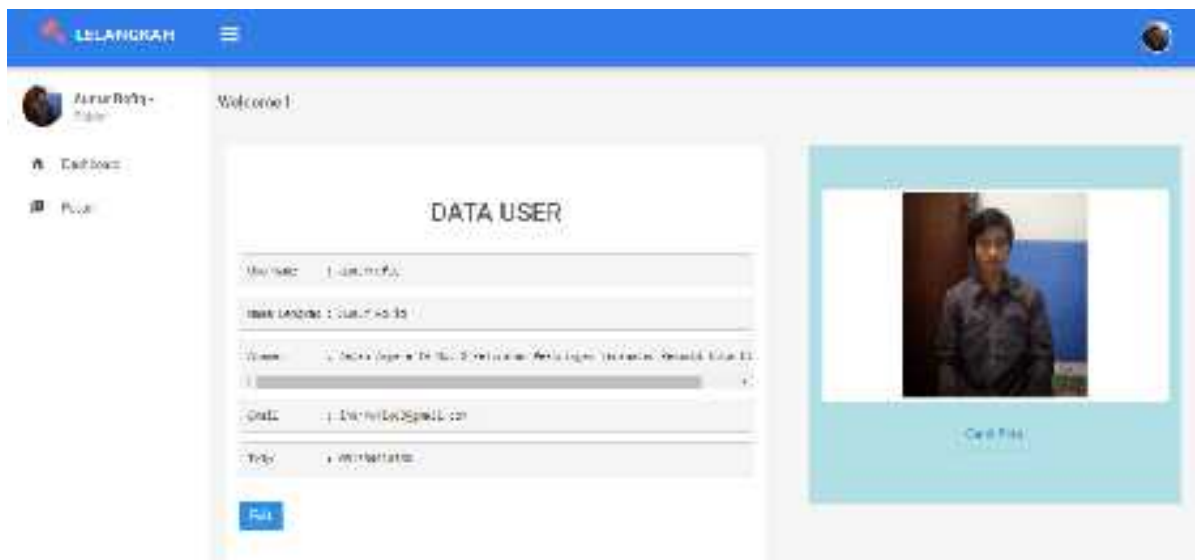

Gambar14.Halaman Menu Utama Bidder

Setelah login bidder dapat ke menu dashboard untuk melihat profil serta kirim pesan. 


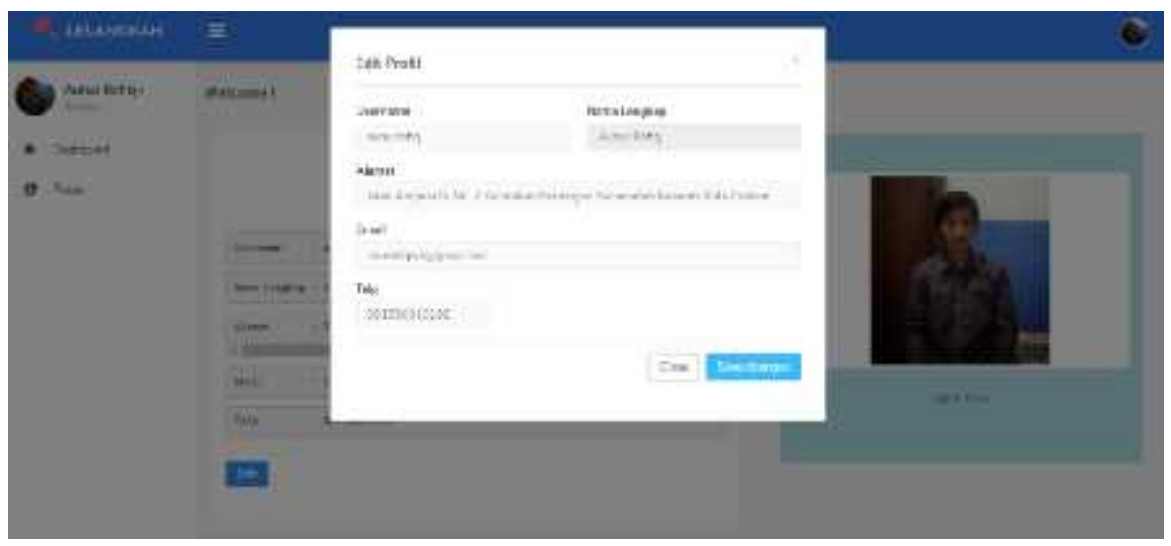

Gambar15.Halaman Menu Edit Profil

Pada menu utama bidder dapat membeli saldo untuk mengikuti lelang dengan mengisi form tersebut serta mengirim foto bukti transfer.
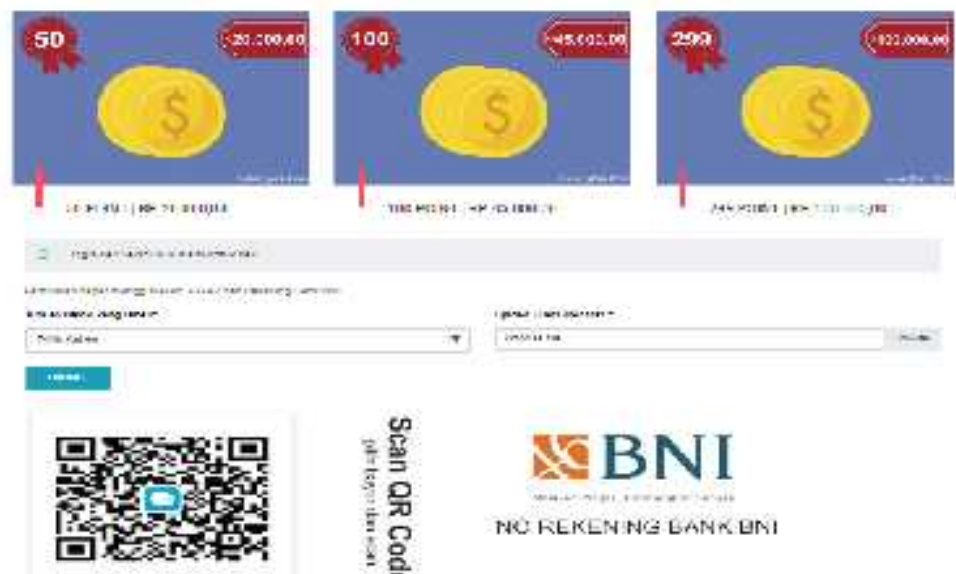

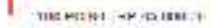
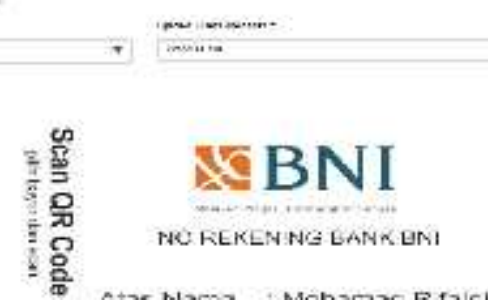

Gambar16.Halaman Menu Beli Saldo

Pada menu ini bidder dapat memberikan penawaran atau bid untuk produk yang di pilih.

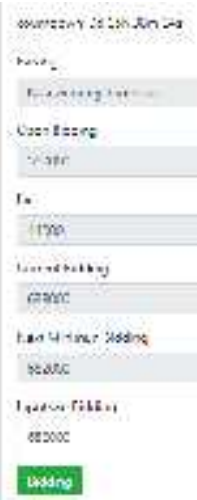

Gambar17.Halaman Menu Bid

Aplikasi Marketplace Dengan Sistem Lelang Berbasis Web Menggunakan Metode Concurrency Control (Timestamp)-( Mohamad Rifaldi, Ridho Taufiq Subagio, Kusnadi) 
Menu ini berfungsi untuk para bidder memberikan penawaran nya untuk mendapatkan barang yang dinginkan.

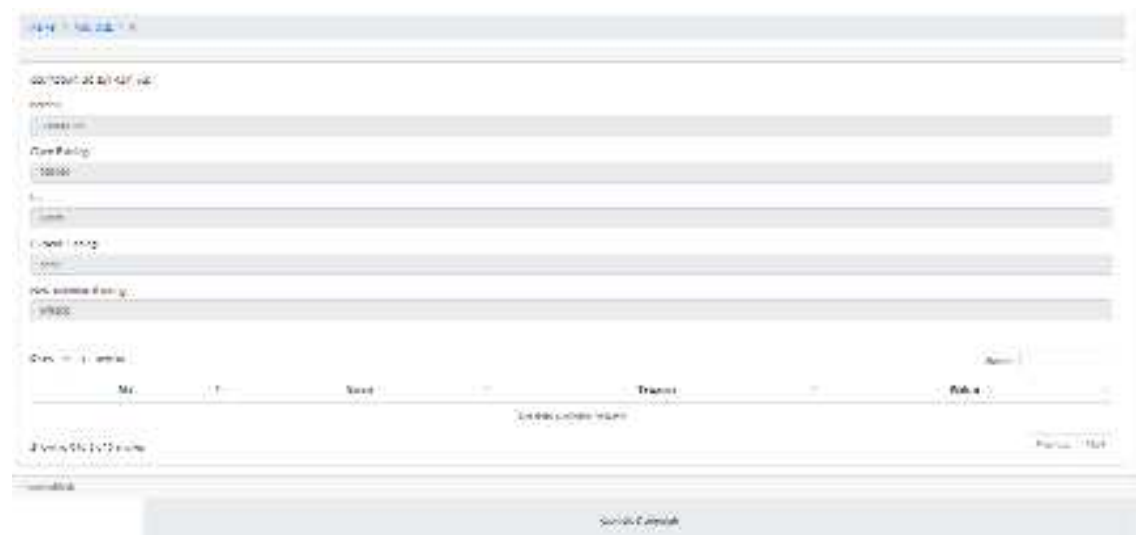

Gambar18.Halaman Menu Detail Produk

\section{KESIMPULAN DAN SARAN}

\subsection{Simpulan}

Kesimpulan yangdiambil daripembuatan aplikasi iniantaralain:

1. Aplikasi lelang ini sudah dapat memberikan peluang pemanfaatan barang seni untuk dilelangkan.

2. Terciptanya sebuah aplikasi marketplace berbasiskan web yang dapat digunakan untuk membantu mempermudah proses pelelangan suatu barang seni serta untuk mencangkup pasar pelelangan yang lebih luas.

3. Dengan proses lelang online dapat mengoptimalkan waktu proses pelelangan secara praktis, sehingga semua orang, kapan dan dimana saja dapat mengikuti lelang.

4. Aplikasi ini dibangun dengan menggunakan metode concurrencycontrol dengan cara pemberian tanda waktu disetiap data dengan menggunakan teknik timestamp untuk menghasilkan data yang akurat dan konsisten.

\subsection{Saran}

Adapun saran-saranyangpenulis berikan untuk pengembangan aplikasi selanjutnya antralain:

1. Aplikasi ini sebaiknya diimplementasikan ke dalam pemrograman android atau mobilephone, sehingga dapat menjangkau pengguna bergerak (mobileuser).

2. Pembuatan aplikasi lelang ini, lebih baik ditambah dengan fitur realtimewebsite, paymentgateway serta keranjang belanja seperti marketplace pada umumnya tetapi tetap penjualan produk harus melalui proses lelang.

3. Tidak dilengkapi fitur SMS Gateway sebagai notifikasi langsung, dalam hal konfirmasi ke bidder pada saat telah proses pelelangan telah terjadi kesepakatan penawaran.

\section{REFERENSI}

[1] Ronny, Toko online,concurrencycontrol, timestamp. DenganLK Sistem Lelang, Vol. I, eJournal Fakultas Teknologi Informasi Universitas Islam Kalimantan, 2013.

[2] Adhiyan Abdiel Nugraha, Nova Rijati, Aplikasi E-Lelang Barang Dengan Metode The ConccurentOfDevelopment, Teknik Informatika, Universitas Dian Nuswantoro 2015.

[3] Opiida, E-Marketplace, https://tokokhalista.wordpress.com/2014/04/18/pengertian-e-marketplace/, diakses 20 Desember 2016, pukul 22.05.

[4] Salim HS, Perkembangan Hukum Jaminan di Indonesia, Rajawali Pers, Jakarta, 2011. 